DOI:10.33099/2311-7249/2019-34-1-127-132

УДК 623.418 .4

Юрій Миколайович Коломісць

Сергій Михайлович Коротін (кандидат технічних наук)

Національний університет оборони Украӥни імені Івана Черняховського, Київ, Украйна

\title{
АНАЛІЗ МОЖЛИВОСТЕЙ ІСНУЮЧИХ СИСТЕМ ОПОВІЩЕННЯ ПРО РАКЕТНУ АТАКУ, ЯКІ ВСТАНОВЛЕНІ НА ЛІТАЛЬНИХ АПАРАТАХ
}

Вивчення нових комплексів індивідуального захисту літальних апаратів від всіх типів керованого ракетного озброєння з інфрачервоними головками самонаведення та від радіокерованого ракетного озброєння, які відіграють важливу роль у виконанні завдань льотними екіпажами в сучасних умовах бойових дій, з кожним днем набирає все більшої актуальності. Цей напрям став предметом наукових досліджень науково-дослідних установ Міністерства оборони і державних підприємств обороннопромислового комплексу Украӥни. Результати проведеного аналізу можливостей існуючих систем оповіщення про ракетну атаку, які встановлені на літальних апаратах, розроблених в провідних країнах світу, дали змогу автору статті прийти до визначення напряму дослідження перспективних систем захисту літальних апаратів від засобів протиповітряної оборони. Одним із перспективних таких досліджень є створення автоматизованого комплексу активного захисту літака, з метою підвищення ефективності застосування бортових систем управління озброєнням літака. У статті приведено аналіз існуючих систем оповіщення про ракетну атаку провідних країн світу від ураження ракетами класу “повітря-повітря” та “поверхня-повітря”. За результатами проведеного автором аналізу технічної $i$ наукової літератури, запропоновано перспективні напрями розвитку автоматизованого комплексу активного захисту літальних апаратів Повітряних Сил Збройних Сил Украӥни.

Ключові слова: літальний апарат; керовані ракети; системи оповіщення про ракетну атаку; ефективність захисту літаків.

\section{Вступ}

Практично в усіх сучасних збройних конфліктах, де мало місце протистояння регулярних армій, захисту літальних апаратів від сучасних систем протиповітряної оборони відводилась важлива роль [2].

Основну загрозу літальним апаратам (ЛА) на сьогодні становлять зенітно-ракетні та зенітногарматні комплекси, до складу прицільних систем яких можуть входити радіолокаційні станції (РЛС), оптико-електронні системи 3 тепловізійними та телевізійними системами й лазерним далекоміром, а також переносні зенітноракетні комплекси, зенітні установки, протитанкові керовані ракети, гранатомети, некеровані реактивні снаряди та противертольотні міни [8].

Захист літаків (вертольотів) на сьогодні вимагає розширення можливостей та удосконалення характеристик протидії новітнім зразкам систем ППО [6].

Керовані ракети (КР) завдяки високій швидкості і дальності польоту, маневреності, складності виявлення та точності наведення стали одною з головних загроз для літальних апаратів (ЛА) різного призначення. Захист бойових, транспортних літаків і вертольотів від керованої ракетної зброї $є$ однією 3 складніших проблем авіцції.

Постановка проблеми. Для знищення повітряних цілей сучасними КР класів “поверхняповітря" та “повітря-повітря” використовуються різні системи наведення [3]. Більшість ракет оснащена активними, пасивними і напівактивними радіолокаційними головками самонаведення (РЛ ГСН), пасивними інфрачервоними (ІЧ) та ультрафіолетовими (УФ), а також лазерними головками самонаведення активного й пасивного типів. У деяких з КР застосовуються комбіновані системи наведення.

За останнє десятиліття причини бойових втрат літаків і вертольотів, свідчать про те, що понад $90 \%$ ЛА було знищено ракетами, оснащеними пасивними ІЧ ГСН, и до $45 \%$ - КР з РЛ ГСН. Більша частина втрат є наслідком застосування КР класу “поверхня- повітря".

На теперішній час більш ніж у 20-ти країнах виробляється понад 100 типів таких ракет. Серед КР класу “поверхня-повітря" найбільш розповсюдженими $є$ переносні зенітні ракетні комплекси (ПЗРК) [7].

Найбільш ефективними вважаються керовані 
авіаційні ракети класу “повітря-повітря” з ІЧ ГСН, що мають амплітудно-фазову (АФ) і частотнофазову (ЧФ) обробку (модуляцію) сигналу. Застосування часово-імпульсної модуляції використовується в останніх розробках ракет класу “повітря-повітря” і ПЗРК.

Для захисту від КР сучасні літальні апарати використовують специфічні засоби електронної війни - станції виявлення та попередження про загрозу ракетного нападу, а також засоби активної i/або пасивної протидії їй [8].

У стадії розробки і виробництва знаходяться засоби захисту від ракет, які можна розділити на наступні групи:

засоби активних завад (ЗАЗ), що працюють як 3 лазерним, так і 3 звичайним (некогерентним) джерелом ІЧ випромінювання;

засоби пасивних завад (ЗПЗ);

засоби попередження пілота про пуск ракети (ЗППР).

Залежно від вигляду i потужності випромінювання на вході ІГС активні завади поділяються, у свою чергу, на ті, що наносять ураження, засвітлюють і що дезорієнтують головки самонаведення.

Для широко використовуваних в оптоелектронних приладах матеріалів гранична щільність випромінювання для імпульсів тривалістю біля $10^{7}$ с становить від $10^{6}$ до $10^{7} \mathrm{BT} / \mathrm{cm}^{2}$, що відповідає рівню енергії від 0,1 до 1 Дж/ $\mathrm{cm}^{2}[5]$.

При щільності енергії порядку 1,5 Дж/см² відбувається швидкий нагрів приймача променевої енергії (ППЕ), в результаті чого він руйнується. При нижчих рівнях випромінювання відбувається локальне ураження фоточутливого шару, в результаті чого здійснюється ефект засвітлювання ГСН. Час відновлення працездатності ППЕ може складати від сотих часток секунди до декількох годин, що приводить до зриву супроводження ракетою цілі. При дії завади 3 рівнем $10^{-6} \ldots 10^{-4}$ Вт/см ${ }^{2}$ відбувається силове придушення сигналу від цілі. Але дія завади на інфрачервоні головки самонаведення припиняється безпосередньо після ії зняття.

Модульовані завади вимагають найменшої щільності випромінювання на вході ІГС, яка повинна перевищувати рівень опромінення ракетою, яка атакується, в 2-3 рази. Проте, вигляд модуляції завади повинен відповідати методу обробки сигналу в ІГС придушеної ракети, а частоти модуляції завади i частоти модуляції випромінювання цілі повинні збігатися до 3-5\%. Системи такого типу повинні мати інформацію про типи ІГС, що застосовуються, або протидіяти лише одному типу ІГС.

Засоби пасивних завад включають хибні теплові цілі (ХТЦ) і аерозольні. Аерозольні поділяться в свою чергу на маскувальні та імітаційні. Маскувальні аерозольні хмари призначені зменшити сигнал від цілі на вході ІГС і поряд 3 імітаційними в даний час широко не застосовуються, зважаючи на слабку ефективність і складність технічних рішень.

Ефективність аерозолю визначається як загальна маскуюча здатність, що характеризується площею поверхні, що може бути скрита за допомогою 1 кг аерозольного засобу, що забезпечує послаблення випромінювання у видимому діапазоні довжини хвиль у 80 разів. Наприклад, ефективність білого фосфору $1350 \mathrm{~m}^{2} / \kappa г$, гексахлоретанової суміші $900 \mathrm{~m}^{2} / \kappa г$, масла, виробленого з нафти $630 \mathrm{~m}^{2} / к г$ [5].

Таким чином, протистояти сучасним зразкам ППО доволі складно. Тому, беручи до уваги характер повітряного бою, автором статті розглядаються шляхи удосконалення системи управління озброєнням (СУО) літаків, які знаходяться на озброєнні ПС ЗС України, що дасть можливість 3 достатньо великою імовірністю захистити екіпаж літального апарату від ракет класу “повітря-повітря” і “поверхня-повітря”.

В статті проведено аналіз систем оповіщення про ракетну атаку передових країн світу.

\section{Аналіз останніх досліджень і публікацій.}

На кожному літаку (вертольоті) незалежно від його призначення вимагається мати як мінімум систему, що забезпечує виявлення та попередження про загрозу. Вона повинна своєчасно виявляти загрозу, попереджати про це екіпаж ЛА і в автоматичному режимі видавати команди на застосування засобів активної та пасивної протидії [7].

Станції попередження про ракетну атаку застосовуються на літаках і вертольотах у наступних варіантах: у складі інтегрованих комплексів індивідуального захисту та активної оптоелектронної протидії; сумісно 3 приймачами попередження про опромінення літака (вертольоту), радіолокаційними станціями управління вогнем і наведення ракет, активними РЛ ГСН КР та автономно. Їх принцип дії, ознаки загрози ракетної атаки, інтенсивність та потужність випромінювання ракет детально розглянуто у [7].

Метою статті с проведення аналізу можливостей існуючих систем оповіщення про ракетну атаку літальних апаратів, основних переваг та недоліків, i на підставі цього запропонувати шляхи підвищення ефективності їх застосування.

\section{Виклад основного матеріалу дослідження}

На озброєнні передових країн світу знаходяться станції попередження про ракетну атаку, що виготовлені у США, Німеччині і Великобританії (AN/AAR-58, AN/AAR-47, AN/AAR-54/PMAWS, AN/AAR-57/CMWS, 
AN/AAR-60 MILDS, AN/AAR-60 (V) 2 MILDS F, AN/AAQ-37, DIRCM тощо). Станції національного виготовлення мають на озброєнні тільки Франція (DDM2000， DDM-Prime), ПАР (MAW-200) та Ізраїль (Guitar 300, Guitar 350, PAWS, PAWS 2) [7, $14,12,13,15]$.

На сьогодні на ЛА Збройних Сил України (ЗС України) встановлені засоби захисту, до складу яких входять системи попередження про радіолокаційне опромінення, системи постановки активних завад, а також пристрої відстрілу хибних цілей [8].

Основні системи захисту авіації Повітряних Сил Збройних Сил України такі:

для тактичної авіації: системи попередження про опромінення СПО-15 - всі типи літаків; станції активних перешкод МиГ-29 - Л-203Б, Су-24М - СПС-161, Су-25 - СПС-141, СПС-142 контейнерного типу); автомати викидання хибних цілей (літаки Су-27 та Су-24М - АПП-50А, МиГ-29 - БВП-30-26, Су-25 - АСО-2В); системи попередження про пуск ракети "МАК-УЛ" (тільки на літаках Су-24M) [8];

для транспортної авіації: системи попередження про опромінення СПО-10 (літаки типу Іл-76МД та Ан-26); станції активних перешкод СПС-5М та СПС-151 (літаки типу Іл-76МД); автомати викидання хибних цілей АСО2И-Е7p та АПП-50 (літаки типу Іл-76МД) [8].

Вертольоти типу Ми-8 обладнані станціями оптико-електронного придушення Л-166 “Липа" та автоматами викидання хибних цілей АСО-2В. Літаки Ан-24 і Ан-30 не обладнанні системами захисту від засобів ППО. [6]

Основні характеристики та переваги вищевказаних систем наведено у літературі [7, 6, $10,14,11]$.

Поряд 3 тим, незважаючи на переваги даних систем, існує ряд недоліків.

Щодо ІЧ датчиків, які поділяються на ті, що сканують і миттєвого огляду.

Датчики, що сканують, не дозволяють швидко виявити та встановити сигнатуру об'єкту, який загрожує. Це призводить до видачі команд екіпажу ЛА та засобам протидії з певним часом запізнення.

Датчики миттєвого огляду мають меншу чутливість ніж ті, що сканують.

Системи 3 ІЧ датчиками малоефективні при виконанні завдань на гранично малих висотах, у зв'язку 3 сильним тепловим фоном підстильної поверхні, швидко зростає ймовірність помилкових спрацьовувань.

Системи з УФ датчиками показали залежність можливості виявлення ультрафіолетової компоненти сигнатури ракети від концентрації озону в атмосфері [7].

До недоліків лазерної системи придушення i протидії відносяться:

необхідність генерування завадового випромінювання одночасно на декількох довжинах хвиль для забезпечення придушення IЧ головок самонаведення;

застосування високоточної системи наведення лазерного променю на ціль;

вузька зона протидії бортового лазера в силу обмежень по куту відхилення лазерного променю;

необхідність формування потужного потоку лазерного випромінювання на великих відстанях, внаслідок чого великі масо-габаритні показники [1].

Основні недоліки засобів попередження про радіолокаційне опромінення та станцій постановки активних завад, які встановлені на ЛА ЗС України:

орієнтовані на виявлення радіолокаційного опромінення та постановку активних завад РЛС зенітно-ракетних комплексів та бортових РЛС літаків західного виробництва;

не повною мірою забезпечують ідентифікацію РЛС радянського виробництва й сучасних РЛС іноземного виробництва за діапазонами випромінювання та за режимами роботи, що не дає змоги здійснювати ефективну протидію [8].

Аналіз існуючих систем дає можливість зробити висновок, що жодна 3 вищенаведених систем не дозволяе 3 високою імовірністю захистити льотний екіпаж від ракет класу “поверхня-повітря" та “повітря-повітря". Існуючі на озброєнні засоби захисту не забезпечують комплексного захисту ЛА від КР з різними типами головок самонаведення.

Сучасні БКО літальних апаратів, як правило, включають до своєї структури два основних взаємопов'язаних комплекси: радіоелектронної та оптико-електронної протидії, які структурно створюються окремо у зв'язку 3 різними фізичними принципами розповсюдження та оброблення радіо і оптичних хвиль, відмінністю елементної бази, яка використовується для побудови обладнання, та разом 3 системами попередження про ракетний напад, радіолокаційне (оптоелектронне) опромінювання i приладами викиду хибних цілей інтегруються в єдиний автоматизований комплекс [9].

Побудова сучасних БКО показує, що існують два основні концептуальні підходи до їх побудови, в особливості їх складової частини - комплекту ОЕП [9].

Перший підхід ОЕП базується на використанні для визначення факту пуску керованих ракет і iii поточних координат високоточних матричних УФ сенсорів (або пеленгаційних приладів на імпульсно-доплеровських принципах оброблення сигналів) та лазерних пристроїв (генераторів) для знищення (здійснення збою наведення) теплових ГСН керованих ракет. В цьому підході важливим фактором $\epsilon$ точне визначення і відслідкування поточних координат ракети для наведення на неї ГСН гостронаправленої лазерної системи. 
Прикладом такої системи $є$ системи: "MANTA", яка розроблена корпорацією російських підприємств спільно 3 європейською корпорацією Indra; "Guardian", "Nemesis" американської корпорації Northrop Grumman [9, 4].

В основу другого підходу покладене те, що не обов'язкове точне визначення поточних координат КР, а достатньо тільки визначити факт пуску i приблизний напрямок, після чого створюється всеракурсний захист ЛА за рахунок застосування станції активних некогерентних модульованих ІЧ завад. При цьому, здійснюється зрив наведення або розхитування голівки наведення КР, тим самим підвищується поле дії ХТЦ.

Прикладами ОЕП, які розроблено за цим принципом, $є$ : бортова станція імітуючих активних завад для індивідуального захисту ЛА від КР з ІЧ ГCH - LAIRCM AN/AAQ-24(v) американської корпорації "Northrop Grumman"; система "Президент-С" (РФ); комплекс оптикоелектронних завад станції “Квадрос" вітчизняного виробництва [9].

На сьогоднішній день США у рамках проекту HKSPCS (Hard Kill Self-Protection Countermeasure System, система самозахисту на принципі фізичного знищення) почали розробку нових засобів самозахисту для ЛА, що зможуть збивати КР, які наближаються до ЛА.

Нова система виготовлятиметься у двох варіантах: перший це система, яка встановлюється усередині планера літака; другий - підвісний контейнер, що буде вміщати достатню кількість засобів протидії для знищення 4-10 ракет [16].

Виходячи 3 проведеного аналізу існуючих систем захисту літаків провідних країн світу та авіації Збройних Сил України, враховуючи перспективи розвитку бортових комплексів оборони літальних апаратів зрозуміло, що перспективні системи захисту літальних апаратів від засобів протиповітряної оборони мають забезпечувати:

виявлення радіолокаційного, лазерного опромінення;

визначення типу працюючої радіолокаційної станції та засобів ураження, які використовуються проти літального апарату;

визначення часу, напрямку (траєкторії), дальності пуску засобів ураження із візуальною індикацією та звуковим оповіщенням;

вибір оптимальної програми використання засобів протидії й приведення їх у дію у тому числі і без втручання льотчика.

Таким чином перспективна система захисту літальних апаратів відповідно до вимог, які до неї пред’являються, повинна включати:

систему попередження про опромінення літальних апаратів (радіолокаційне, лазерне); систему датчиків виявлення пуску ракет (інфрачервоні, ультрафіолетові);

станції оптико-електронної протидії (у тому числі лазерної);

станції постановки активних радіоелектронних завад (з технологією цифрової пам'яті високих частот);

пристроїв викидання хибних цілей;

бортову ЕОМ для рішення задачі вибору оптимальної програми використання засобів протидії й приведення їх у дію у тому числі і без втручання льотчика.

Одним $з$ перспективних шляхів удосконалення систем управління озброєнням (СУО) літаків, що знаходяться на озброєнні Повітряних Сил ЗС України, $\epsilon$ розроблення та застосування перспективного нового автоматизованого комплексу активного захисту літака, який дозволить в автоматизованому режимі з достатньо великою імовірністю захистити екіпаж літального апарату від ракет класу "повітря-повітря" i “поверхня-повітря” у ближній зоні.

\section{Висновки й перспективи подальших досліджень}

Отже, за результатами аналізу технічної i наукової літератури, практики застосування бортових систем управління озброєнням літаків за останні 25 років, 3 метою підвищення ефективності застосування СУО літака необхідно передбачити:

можливості систем попередження про пуск ракет 3 інфрачервоною (ультрафіолетовою) та радіолокаційною (лазерною) головками самонаведення та систем оптико-електронного придушення;

необхідність витрати льотчиком певного часу на прийняття вірного рішення щодо застосування авіаційного озброєння, засобів захисту в умовах великого обсягу інформації;

низький рівень захисту літака, особливо у ближній зоні задньої напівсфері та на малих і гранично-малих висотах.

Перспективними дослідженнями у даному напрямку є:

розроблення тактико-технічних вимог до комплексу активного захисту літака у ближній зоні та до перспективних керованих ракет класу “повітря-повітря";

визначення точнісних характеристик комплексу активного захисту літака;

удосконалення математичної моделі та розроблення алгоритму, що забезпечує виявлення, захоплення та супроводження повітряної цілі, наведення на неї перспективних керованих ракет класу “повітря-повітря" і знищення повітряної цілі. 


\begin{abstract}
Jimepamypa
1. Гавриш С. В. Создание импульсных газоразрядных источников ИК излучения нового поколения для оптико-электронных систем : дис. д-ра тех. наук : 05.27.02. Москва, 2018. 360 с. 2. Довідник учасника ATO: озброєння і військова техніка Збройних сил Російської Федерації / за заг. ред. А. М. Алімпієва. Харків. Оригінал, 2015. 732 с. 3. Коротін С. М. Методика визначення ефективності застосування керованих авіаційних ракет класу “повітря-повітря" ближньої дії по повітряним цілям / С. М. Коротін: зб. наук. пр. інституту проблем моделювання в енергетиці ім. Г.С. Пухова НАН України. К., 2013. № 66. С. 25-35. 4. Ольгин С. Бортовая авиационная система оптоұектронного противодействия "Немезис". Зарубежное военное обозрение. 2003. № 5. С. 40. 5. Ольгин С. Проблемы оптоэлектронного противодействия. Зарубежное военное обозрение. 2002. № 9. С. 35-41. 6. Скоренький П. Є. Аналіз стану систем захисту літальних апаратів Повітряних Сил Збройних Сил України. Наука і техніка Повітряних Сил Збройних Сил України. 2017. № 2(27). С. 49-51. 7. Фиолентов А. Авиационные станции предупреждения о ракетной атаке. Зарубежное военное обозрение. 2002. № 2. С. 3339. 8. Харченко О. В., Пащенко С. В., Тараненко В. В. Шляхи оснащення літальних апаратів Збройних Сил України засобами захисту. Наука і оборона. 2015. № 2.
\end{abstract}

С. 33-38. 9. Шейн І. В., Борисюк О. П., Андрєєв К. В. Аналіз побудови сучасних бортових комплексів захисту літальних апаратів та обгрунтування необхідності розробки автоматизованого бортового комплексу захисту, його концептуальні основи побудови. Наука i техніка Повітряних Сил Збройних Сил України. 2017. № 2. С. 65-70. 10. Щербак М.В. Противодействие зенитным управляемым ракетам с инфракрасным наведением. Наука, технология, бизнес. 2000. № 5. С. 121. 11. Яшин С. Особенности развития авиационных средств оптико-электронного противодействия для винтокрылых летательных аппаратов ВС США. Зарубежное военное обозрение. 2016. № 10. C. 67-72. 12. AN/AAR-60 (V)2 Missile Warning System for Fighter Aircraft - ITT Exelis Inc., 2012. - URL: http://www.exelisinc.com/solutions/MissileWarning-System/Documents/ITT-Exelis-Missile-WarningSystem-AAR-60.pdf. 13. Chris Pocock. Elbit Will Help Defend Future Gripens. 2013. URL: https://www.ainonline.com. 14. John Haystead. Missile Warning for Fighter Aircraft. The Journal of Electronic Defense. 2015. № 6. P. 26-36. 15. Kasper Rasmussen. Missile Warning and Flare-up for Netherlands F-16. 2017. - URL: https://www.terma.com. 16. Stephen Trimble. USN reveals concept to defend aircraft against missile attack with interceptors. 2018.

URL: https://www.flightglobal.com.

\title{
АНАЛИЗ ВОЗМОЖНОСТЕЙ СУЩЕСТВУЮЩИХ СИСТЕМ ОПОВЕЩЕНИЯ О РАКЕТНОЙ АТАКЕ КОТОРЫЕ УСТАНОВЛЕНЫ НА ЛЕТАТЕЛЬНЫХ АППАРАТАХ
}

\author{
Юрий Николаевич Коломиец \\ Сергей Михайлович Коротин (кандидат технических наук)
}

Национальный университет обороны Украины имени Ивана Черняховского, Киев, Украина

Изучение новых комплексов индивидуальной защиты летательных аппаратов от всех типов управляемого ракетного вооружения с инфракрасными головками самонаведения $u$ от радиоуправляемого ракетного вооружения, которые занимают особенную роль в выполнении задач лётными экипажами в современных условиях боевых действий, с каждым днём набирает всё большей актуальности. Это направление стало предметом научных исследований научно-исследовательских учреждений Министерства обороны и государственных предприятий оборонно-промышленного комплекса Украины. Результаты проведенного анализа возможностей существующих систем оповещения о ракетной атаке, которые установлены на летательных аппаратах, разработанных 6 передовых странах мира, дали возможность автору статьи прийти к определению направления исследования перспективных систем защиты летательных аппаратов от средств противовоздушной обороны. Одним из перспективных таких исследований является создание автоматизированного комплекса активной защиты самолёта, с иелью повышения эффективности применения бортовых систем управления вооружением самолёта. В статье приведён анализ существующих систем оповещчения о ракетной атаке передовых стран мира от поражения ракетами класса “воздух-воздух” $и$ “земля-воздух”. По результатам осуществлённого автором анализа технической и научной литературы, предложено перспективные пути развития автоматизированного комплекса активной защиты летательных аппаратов Воздушных Сил Вооруженных Сил Украиныл.

Ключевые слова: летательный аппарат; эффективность защиты самолётов; управляемые ракеты; системы оповещения о ракетной атаке.

\section{ANALYSIS OF POSSIBILITIES OF THE EXISTENT COMMON MISSILE WARNING SYSTEMS THAT IS SET ON AIRCRAFTS}

\author{
Yurii Kolomiiets \\ Sergii Korotin (Candidate of technical sciences)
}

Modern Information Technologies in the Sphere of Security and Defense $\mathcal{N} N$ 1(34)/2019 ISSSN2311-7249(Print)/ISSSN2410-7336(Onfine) 


\section{National Defense University of Ukraine named after Ivan Cherniakhovsky, Kyiv, Ukraine}

The study of new systems of individual protection of aircraft from all types of guided missile weapons with infrared homing heads and radio-controlled missile weapons, which occupy a special role in the performance of tasks by flight crews in modern combat conditions, is gaining increasing relevance every day. This area has been the subject of scientific research institutions of the Ministry of Defense and state-owned enterprises of the military-industrial complex of Ukraine. The results of the analysis of the capabilities of existing missile attack warning systems, which are installed on aircraft developed in advanced countries of the world, enabled the author to come to the definition of the direction of research of promising systems for protecting aircraft against air defense systems. One of the promising such studies is the creation of an automated complex for the active protection of the aircraft, with the aim of increasing the efficiency of using the onboard aircraft weapon control systems. The article provides an analysis of existing warning systems for a rocket attack of the advanced countries of the world from "air-to-air" and "air-to-surface" missiles. Existing common missile warning systems of advanced countries from shut downing the "air-to-air" and "air-to-surface" missiles were studied in this article. According to the results of the analysis of technical and scientific literature carried out by the author, offered the perspective directions of developing an automated complex of active protection of aircraft of Ukrainian Air Force.

Keywords: common missile warning systems; aircraft, missiles.

\section{References}

1. Gavrish S. V. Creation of pulsed gas-discharge sources of infrared radiation of a new generation for opticalelectronic systems [Sozdanie impul'snyh gazorazryadnyh istochnikov IK izlucheniya novogo pokoleniya dlya optikoehlektronnyh sistem]: thesis for the degree of Doctor of Technical Sciences. Moscow, 2018. 360 p. 2. Reference book of the ATO participant: armament and military equipment of the Armed Forces of the Russian Federation [Dovidnyk uchasnyka ATO: ozbroiennia i viiskova tekhnika Zbroinykh syl Rosiiskoi Federatsii] / A. M. Alimpiiev. Kharkiv. Original, 2015. 732 p. 3. Korotin S. M. Method for determining the effectiveness of the used of the missiles air-to-air for air targets [Metodyka vyznachennia efektyvnosti zastosuvannia kerovanykh aviatsiinykh raket klasu "povitria-povitria" blyzhnoi dii po povitrianym tsiliam] / S. M. Korotin. Collection of scientific works of the Modeling Problems in the energy Institute named after G.E. Puhov NAS of Ukraine. K., 2013. №.66. p.25-35. 4. Ol'gin S. Onboard aviation system of opto-electronic countermeasures "Nemesis" [Bortovaya aviacionnaya sistema opto-ehlektronnogo protivodejstviya "Nemezis"]. Foreign military review. 2003. № 5. P. 40. 5. Ol'gin S. Optoelectronic countermeasures [Problemy optoehlektronnogo protivodejstviya]. Foreign military review. 2002. № 9. P. 35-41. 6. Skorenkyi P. Ie. Analysis of state of aircraft protection systems of the Air Force of Ukraine [Analiz stanu system zakhystu litalnykh aparativ Povitrianykh Syl Zbroinykh Syl Ukrainy]. Science and technology of Ukrainian Air Force. 2017. № 2(27). P. 49-51. 7. Fiolentov A. Aircraft missile warning stations [Aviacionnye stancii preduprezhdeniya o raketnoj atake]. Foreign military review. 2002. № 2. P. 33-39. 8. Kharchenko O. V., Pashchenko S. V., Taranenko V. V. Ways of equipping the aircraft of the Armed Forces of
Ukraine with means of protection [Shliakhy osnashchennia litalnykh aparativ Zbroinykh Syl Ukrainy zasobamy zakhystu]. Science and defense. 2015. № 2. P. 33-38. 9. Shein I. V., Borysiuk O. P., Andrieiev K. V. Analysis of the construction of modern airborne aircraft protection complexes and justification for the need to develop an automated airborne defense complex, its conceptual foundations of construction [Analiz pobudovy suchasnykh bortovykh kompleksiv zakhystu litalnykh aparativ ta obgruntuvannia neobkhidnosti rozrobky avtomatyzovanoho bortovoho kompleksu zakhystu, yoho kontseptualni osnovy pobudovy]. Science and technology of Ukrainian Air Force. 2017. № 2. P. 65-70. 10. Shcherbak M. V. Counteraction of infrared-guided anti-aircraft missiles [Protivodejstvie zenitnym upravlyaemym raketam $\mathrm{s}$ infrakrasnym navedeniem. Science, technology, business. 2000. № 5. 121 p. 11. Yashin S. Features of the development of aviation optical-electronic countermeasures for helicopters of the US Armed Forces [Osobennosti razvitiya aviacionnyh sredstv optiko-ehlektronnogo protivodejstviya dlya vintokrylyh letatel'nyh apparatov VS SSHA]. Foreign military review. 2016. № 10. P. 67-72. 12. AN/AAR-60 (V)2 Missile Warning System for Fighter Aircraft - ITT Exelis Inc., 2012.

URL: http://www.exelisinc.com/solutions/Missile-WarningSystem/Documents/ITT-Exelis-Missile-Warning-SystemAAR-60.pdf. 13. Chris Pocock. Elbit Will Help Defend Future Gripens. 2013. - URL: https://www.ainonline.com. 14. John Haystead. Missile Warning for Fighter Aircraft. The Journal of Electronic Defense. 2015. № 6. P. 26-36. 15. Kasper Rasmussen. Missile Warning and Flare-up for Netherlands F-16. 2017. - URL: https://www.terma.com. 16. Stephen Trimble. USN reveals concept to defend aircraft against missile attack with interceptors. 2018. URL: https://www.flightglobal.com. 